\title{
Correction to: Chinese adult higher education as a heterotopia
}

\section{Shanshan Guan ${ }^{1}$ (D) E Erik Blair ${ }^{2}$ (D)}

Published online: 6 July 2020

(C) Springer Nature B.V. 2020

\section{Correction to: Higher Education https://doi.org/10.1007/s10734-020-00552-z}

The article Chinese adult higher education as a heterotopia, written by Shanshan Guan and Erik Blair, was originally published electronically on the publisher's internet portal (currently SpringerLink) on 05 May 2020 with open access.

With the author(s)' decision to step back from Open Choice, the copyright of the article changed on 02 July 2020 to (C) Springer Nature B.V. 2020 and the article is forthwith distributed under the terms of copyright.

The original article has been corrected.

Publisher's Note Springer Nature remains neutral with regard to jurisdictional claims in published maps and institutional affiliations.

The online version of the original article can be found at https://doi.org/10.1007/s10734-020-00552-z

Shanshan Guan

guanss0123@163.com

Erik Blair

erik.blair@uwl.ac.uk

1 Department of Education, Faculty of Education, East China Normal University, Shanghai, China

2 School of Higher Education Research and Development, University of West London, London, UK 